\title{
Model of Agricultural Land Use Change and Effects on Social Economy Condition of Local in East Lombok Regency
}

\author{
Cahyadi Nugroho \\ Master Program Student of Geography Education \\ Faculty of Social Science, Universitas Negeri Padang, INDONESIA \\ Email: cahyadinugroho7@gmail.com
}

\begin{abstract}
The purpose in this research to discuss about the change of agricultural land, social economy condition of local in East Lombok Regency, and the planning model of land conversion to social economy of local in East Lombok Regency. The type of research in this study used applied research. Data analysis used GIS analysis method through ArcGIS software to get the change of agricultural land use into built up area in East Lombok Regency, social economy condition through statistic analysis and modeling through ISM analysis. The results of the research are: 1) The conversion of agricultural land into built up area in East Lombok Regency from 2012 until 2015 increases the extent which commonly used local for tobacco plantations; 2) the social economy condition of local in East Lombok Regency, in terms of profession, most of the people are farmers, traders and services, in economy productivity of East Lombok Regency derived from agricultural products and services, East Lombok local income most of them who work as agricultural laborers and service workers have a low income because not landowners or services. 3) social economy planning model based on land use change in East Lombok is to empower communities based on the potential of each sub-district by optimizing agricultural tourism, cultural tourism, integrated CBD through the role of government and local in land use which managed by local and supported by infrastructure, tourism promotion, and government regulations.
\end{abstract}

Keywords: Land Use Change, Social Economy, East Lombok Regency

\section{Introduction}

Land use is a form of exploitation or function of the embodiment of a land cover form. The term of land use is based on the function of the appearance of land cover for life, it natural or man-made appearance. A visible vegetation appearance, in terms of land use can be distinguished into forests and plantations. The mention depends on human treatment of the land cover. Different forms of livelihood produce a variety of land use. In addition to livelihoods, the need factor will also create a form of land use. Like the needs of the house to bring up residential areas. From the different land use patterns also bring up rural and urban terms because of different land use patterns. According to Lo (1995) an important factor for determining the success of land use mapping and land cover lies in the selection of appropriate classification schemes designed for a particular purpose. A good classification scheme should be simple in explaining each category of use and land cover. Anderson in Lo (1995) considers to functional approach or an activity-oriented approach would be more suitable for space satellite imagery, as a general-purpose classification scheme.

The increasing number of population in a region will affect the increasing of space requirement that trigger growth and development of a region. Basically the development of a region triggered by several aspects of the physical, social, cultural, economy, knowledge and technology. The development of a region from the physical aspect can be observed directly from the land use of an urban area. The development of a physical area may result in the intensification of land use and land use extensification. The pattern of 
development in relatively flat area is generally easy to spread out and evenly distributed. However, several factors that led to the development of a region forced to change the previously agricultural land into settlement areas. Requirement for land at the request of land for the purposes of development in various sectors of activity continues to increase along with the speed of development and population growth, If there is no government interference there will be problems on the domination and utilization.

East Lombok is the one of the regencies located in the administrative area of West Nusa Tenggara Province. Located in the eastern part of Lombok Island with an astronomical position on $116^{\circ}-117^{\circ}$ BT dan $8^{\circ}-9^{\circ}$ LS. East Lombok Regency has long coastline, north of Java Sea in the north, Alas Strait in the east, Indonesia Ocean in the south, Central Lombok Regency and North Lombok Regency in the west. As an area directly adjacent to the waters, East Lombok has a number of small islands called Gili. Based on data from the Department of Marine and Fisheries of East Lombok Regency, there are 35 gili in the waters of East Lombok, 5 among other are Gili Beleq, Gili Bidara, Gili Maringkik, Gili Ree and Gili Sunut are already inhabited. Compared to other regencies / cities in Lombok Island, East Lombok is the largest district with 1,605.55 km², equivalent to 33.88 percent of the total area of Lombok Island reaching 4,738.7 $\mathrm{km}^{2}$ (Badan Pusat Statistik, 2016). Agricultural production in East Lombok has fluctuated. In terms of agricultural land, in 2007, 2010 and 2014 decreased rice production and the size of agricultural areas decreased, corn production in 2013 also decreased followed by decrease in the total area of agricultural land. From the change of agricultural area that occurred during a certain period of time, this study discusses the change of agricultural land that occurred in East Lombok Regency.

\section{Method}

The type of research in this study used applied research. The method is quantitative method. Data collection in the study are field observation, remote sensing data collection of satelite image of East Lombok Regency in 2012 and 2015, and documentation are information documents on local social economy of East Lombok Regency. Data sources in this study through primary data and secondary data. Primary data, was obtained through field observation during research in East Lombok Regency. Secondary data required are East Lombok District Administration Map, Spatial Plans Map of East Lombok Regency, image data of East Lombok Regency, Population Data of East Lombok Regency, supporting data of population and East Lombok Regency spatial. Data analysis used GIS analysis through ArcGIS software is agricultural land use change become built up area in East Lombok Regency and social economy condition through statistical analysis and for modeling through ISM (Interpretative Structural Modelling) analysis.

\section{Result and Discussion}

Land cover related to the type of appearance that exists on the surface of the earth (Lillesand and Kiefer, 1990). There is also mention that land cover depicts vegetation and artificial construction that cover the land surface. The land cover classification based on UNFAO's land cover classification system and ISO 19144-1 Geographic Information - Classification Systems - Part 1: Classification System Structure. The UNFAO cover classification system allows for the monitoring and reporting of land cover changes in a country with international acceptance. UNFAO land cover classification system, more detailed drawn up class, more classes are used. The land cover class is divided into 2 major parts, vegetated and non-vegetated areas. All land cover classes in the vegetation category are derived from a physiognomy conceptual approach consisting of plant form, cover form, plant height and spatial distribution. Whereas in the category of non-vegetated areas, classes detail refers to asper surface cover, distribution or density, and the height or depth of the object (Klasifikasi Penutup Lahan SNI 7645, 2010). 
Land use is the one of main research subjects of global environmental change and sustainable development. The intensity of land use change in response to world population growth and its consequences for ensuring the environment through in-depth study of the transformation ( $\mathrm{Wu}$ et al., 2006). The important factor according to Lo (1995) to determine the success of land use mapping and land cover lies in the selection of appropriate classification schemes designed for a particular purpose. A good classification scheme should be simple in explaining each category of use and land cover. According to land use, most of the land in East Lombok is non-rice fields. In 2015 the area of non-rice farming land reaches 94,365 ha (58.80 percent of East Lombok area) where 55,928 ha is state forest. Non-agricultural land area about 18,427 ha (11.44 percent). Meanwhile, the wetland area reaches 47,763 ha (29,76 percent). Local of East Lombok Regency viewed from profession acpect are $42,69 \%$ as farmer, $9.95 \%$ work in processing industry, 2,66\% in construction, $20,13 \%$ in trading, 4,04\% in transportation and communications, $19,55 \%$ service, and others $0.98 \%$. The change of agriculture land use become built up area in East Lombok Regency seen from the specification of land consisting of paddy fields, not rice field and non-agricultural land changes that occur on paddy fields of 45,813 ha to 47,763 ha, non-rice fields plantations from 38,751 ha to 94,365 ha, and non-agricultural land from 75,991 ha to 18,427 ha in 2012 until 2015. In figure 1 it is seen agricultural land use both wetland are increasing and non-rice fields and non-agricultural land transition occurs.

Percentage of economy growth rate in terms of agriculture annually fluctuates up and down but still growing. In the category of agriculture, forestry and fisheries in 2011,2012 and 2015 the percentage of economy growth of East Lombok Regency has increased compared to other years. The economy growth rate of agriculture in East Lombok Regency is influenced by several trigger factors causing the increasing percentage of economy growth such as land conversion due to economy value of land, facilities and infrastructure, investors, government support, mindset and poverty level.

Non-agricultural land that undergoes this change is due to the economy value of tobacco investors because of the East Lombok region itself many people are turning to the tobacco plantation. On the other hand, the people who are landowners have higher income compared to those who only work as laborers so that the level of poverty in East Lombok Regency is still not sufficient for their needs.

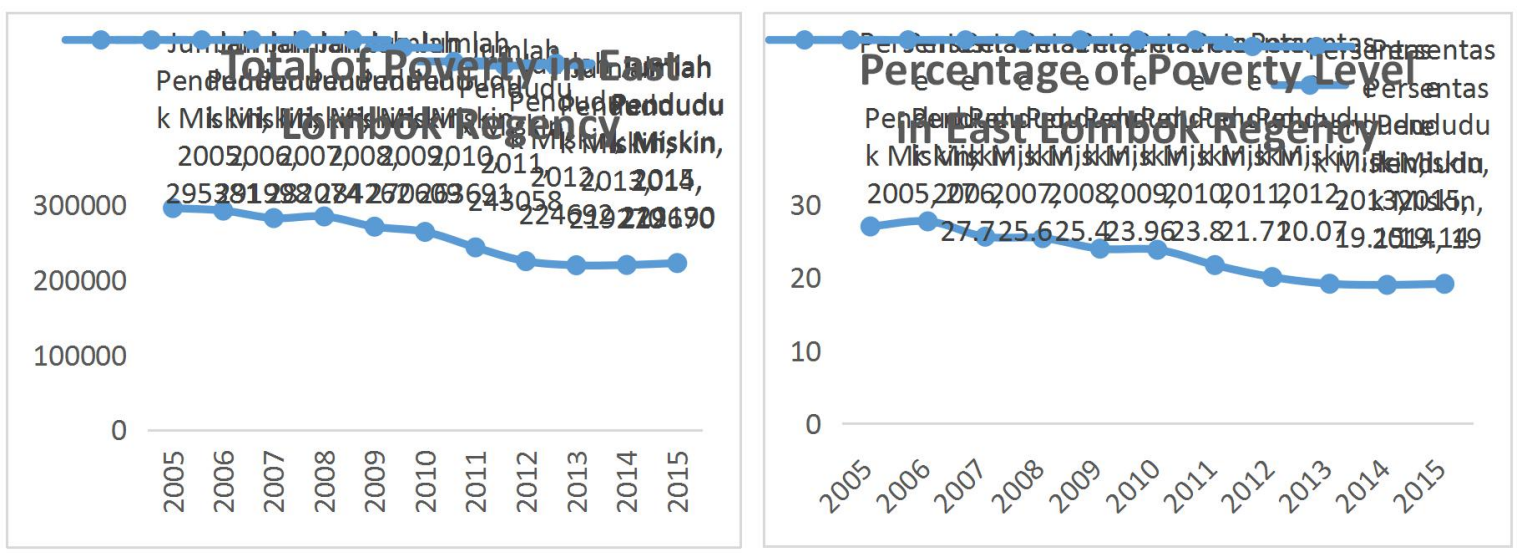

Figure 1. Total and Percentage of Poverty in East Lombok Regency

Based on figure 1, the number of poverty found in East Lombok Regency from 2005 to 2014 has decreased little by little but in 2015 increased again $0.14 \%$. This is triggered by the shifting of land function in which the laborer loses his job whether it is a job in agriculture, trading or services. The results of analysis by using ISM (Interpretative Structural Modeling), known that the problem to social economy seen from the land use change happened in the period 2012 to 2015 got some elements that influence to land use change are 
(1) Economy value of land 2) Facilities and infrastructure, (3) Government support, (4) Investors, (5) People mindset, and (6) Poverty levels can be presented in the table below.

Table 1. Element Factors of Land Use Change in East Lombok Regency

\begin{tabular}{|l|l|l|l|l|l|l|}
\hline & $\begin{array}{l}\text { Economy } \\
\text { Value of } \\
\text { Land } \\
\text { (T1) }\end{array}$ & $\begin{array}{l}\text { Facilities } \\
\text { and } \\
\text { Infrastruct } \\
\text { ure (T2) }\end{array}$ & $\begin{array}{l}\text { Governmen } \\
\text { t Support } \\
\text { (T3) }\end{array}$ & $\begin{array}{l}\text { Investor } \\
\text { s } \\
\text { (T4) }\end{array}$ & $\begin{array}{l}\text { People } \\
\text { Mindset } \\
\text { (T5) }\end{array}$ & $\begin{array}{l}\text { Poverty Level } \\
\text { (T6) }\end{array}$ \\
\hline $\begin{array}{l}\text { Economy Value } \\
\text { of Land (T1) }\end{array}$ & $\mathrm{X}$ & $\mathrm{V}$ & $\mathrm{X}$ & $\mathrm{X}$ & $\mathrm{A}$ & $\mathrm{A}$ \\
\hline $\begin{array}{l}\text { Facilities and } \\
\text { Infrastucture } \\
\text { (T2) }\end{array}$ & & $\mathrm{X}$ & $\mathrm{V}$ & $\mathrm{A}$ & $\mathrm{A}$ & $\mathrm{X}$ \\
\hline $\begin{array}{l}\text { Government } \\
\text { Support (T3) }\end{array}$ & & $\mathrm{X}$ & $\mathrm{O}$ & $\mathrm{O}$ & $\mathrm{O}$ \\
\hline $\begin{array}{l}\text { Investors } \\
\text { (T4) }\end{array}$ & & & $\mathrm{X}$ & $\mathrm{O}$ & $\mathrm{V}$ \\
\hline $\begin{array}{l}\text { People Mindset } \\
\text { (T5) }\end{array}$ & & & & $\mathrm{X}$ & $\mathrm{O}$ \\
\hline $\begin{array}{l}\text { Poverty Level } \\
\text { (T6) }\end{array}$ & & & & & $\mathrm{X}$ \\
\hline
\end{tabular}

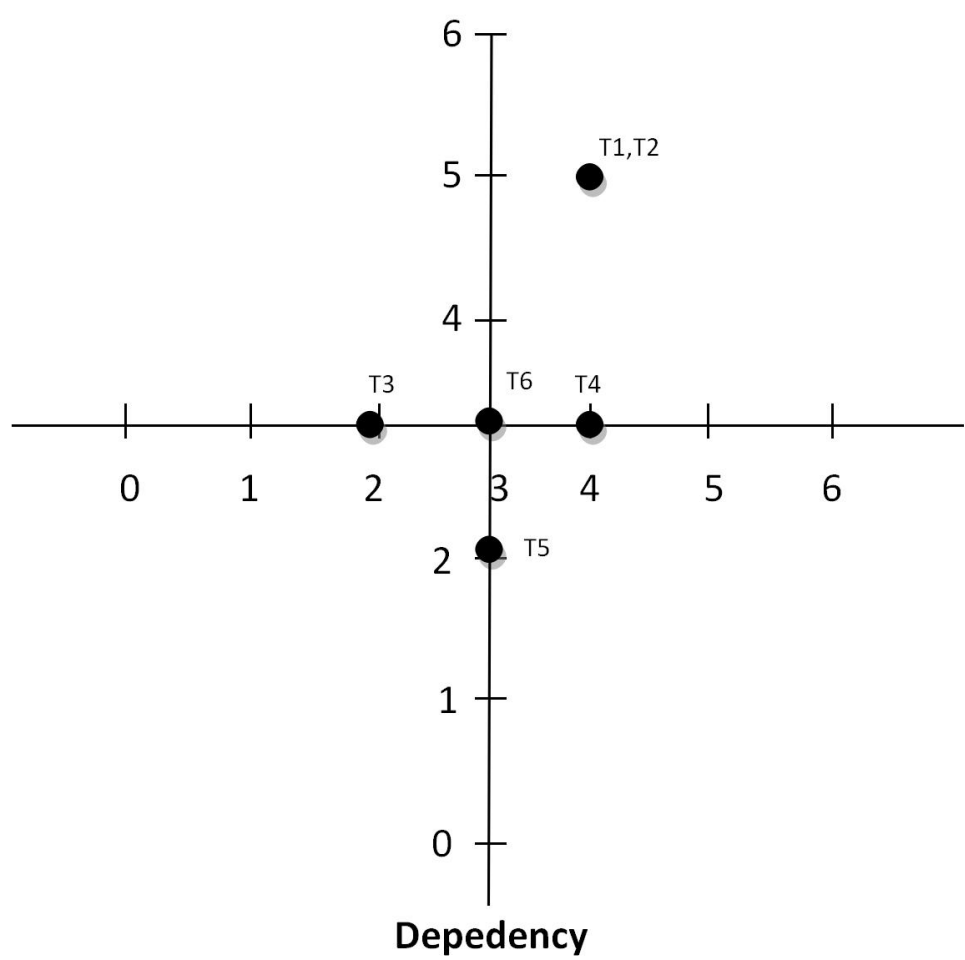

Drive Power

Figure 2. Result of Interpretative Structural Modelling Analysis

Based on figure 2 it shows several factors that influence the existence of land change that impact to local economy in East Lombok Regency factor of economy value of land and facilities and infrastructure are the main problem factor of land change because of economy value of land and infrastructure supported by investor and the number of poor people. In line with the results of field observation and interviews with local leaders and peoples, they switched land to plantations because investors demand for tobacco in high prices so 
many people switch their land. On the other hand, the supporting infrastructure in East Lombok also underlies land use change in both agricultural and tourism areas.

In response occurring land changes during 2012 to 2015 , needs to be implications of the driving factorschange to ensure that land suitability is maintained and the economy value of local are increase. One of implication in the form of land change model and its effect on social economy local to establish the integration between agricultural land use with the potential that exist in East Lombok regency and the role of government through the form of ecotourism which integrated of agricultural tourism, cultural tourism and the Central Business District which is supported by infrastructure, tourism promotion and government policy as well as local culture in tourism management so that economy growth and economy equity in East Lombok Regency can increase in this case can be seen in the following model chart in figure 3 .

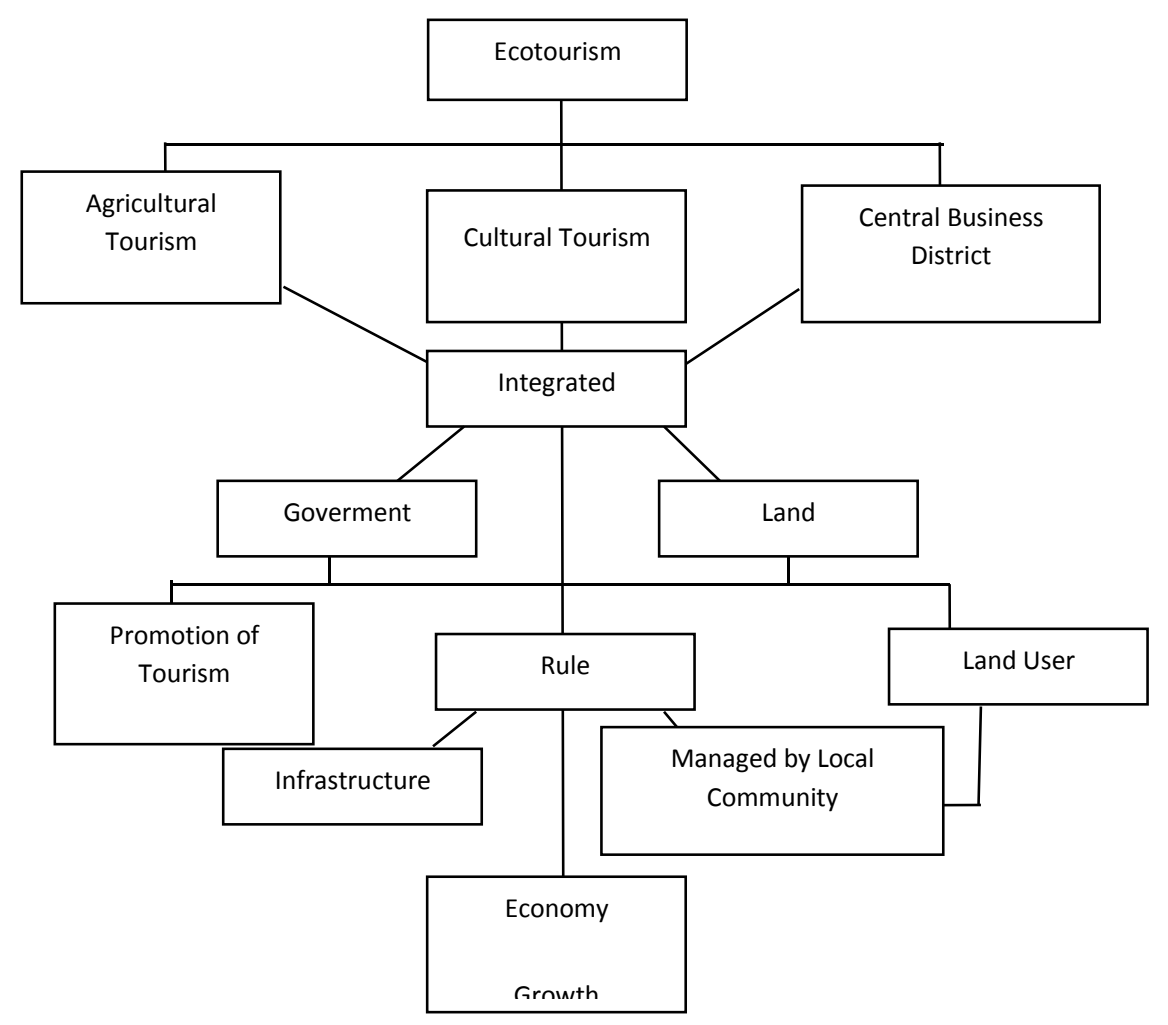

Figure 3. Model of Local Economy Development in East Lombok Regency

\section{Conclusion}

The results shows specific change of agricultural land to built up area during the period of 2012 until 2015 with the expansion of agricultural land is very large compared to built up area. Economyally it is beneficial for people who own land, but for workers instead. Such a shift will trigger an imbalance of the economy if it is not responded quickly by the local government in decision making. It is necessary to draft the policy by optimizing the role of local in economy management in East Lombok Regency and guidance from the government to local so economy of East Lombok regency can be uniform by forming an integration between the use of agricultural land with potential in East Lombok Regency and the role of government through ecotourism form which combination of agricultural tourism, cultural tourism and Central Business 
District being supported by infrastructure, tourism promotion and government policy and local culture in managing tourism so that economy growth and economy equity in East Lombok can increase.

\section{References}

Anne-Helene Matheya, Emina Krcmara, Suzana Dragicevic, Ilan Vertinskya. (2008). “An object-oriented cellular automata model for forest planning problems”. Ecological Modelling 212, 359-371

Badan Pusat Statistik. (2016). "Lombok Timur in Figures 2016”. Jakarta: Katalog BPS 1102001.5203

Badan Standarisasi Nasional. (2010). “Land Cover Classification”. Jakarta: SNI 7645:2010

Batty, M., Couclelis, H., Eichen, M., (1997). "Urban systems as cellular automata”. Environ. Plan. B 24, 159-164.

Couclelis, H., (1997). "From cellular automata to urban models: new principles for model development and implementation". Environ. Plan. B 24, 165.

De Kok, J.L., Engelen, G., White, R., Wind, H.G., (2001). "Modeling land-use change in a decision-support system for coastal-zone management”. Environ. Model. Assess. 6, 123-132.

Dong Jie Guan, Hai Feng Li, Takuro Inohae, Weici Su, Tadashi Nagaie, Kazunori Hokao. (2011). "Modeling urban land use change by the integration of cellular automaton and Markov model". Ecological Modelling 222, 3761-3772

Ilhami. (1990), "Strategies of Urban Development in Indonesia”. Surabaya: Usaha Nasional.

Hermon, D. (2014).“Impacts of Land Cover Change on Climate Trend in Padang Indonesia”. J. International Journal Geography. Yogyakarta: Gadjah Mada University

Hidajat, Janthy Trilusianthy. (2014). "Sustainable Residential Area Management Model in Jabodetabek Metropolitan Suburb”. Dissertasion. Bogor: Bogor Agricultural Institute.

Lillesand dan Kiefer, 1990. "Remote Sensing and Image Interpretation (R. Dubahri Translation)". Yogyakarta: Gadjah Mada University Press.

Lo, C.P. (1995). “Applied of Remote Sensing (B. Purbowaseso Translation)". Jakarta: University of Indonesia.

Mitsova, Diana. (2011)." A cellular automata model of land cover change to integrate urban growth with open space conservation". United States: Journal of Landscape and Urban Planning 99 (2011) 141-153.

Pabundu, Tika. (2005). “Geography Research Method”. Jakarta : Bumi Aksara

Ward, D.P., Phinn, S.R., Murray, A.T., (2000). Monitoring growth in rapidly urbanizing areas using remotely sensed data. Professional Geographer 52, 371-386.

White, R., Engelen, G., (2000). High-resolution integrated modeling of spatial dynamics of urban and regional systems. Comput. Environ. Urban Syst. 24, 383-400.

Wu, Q., Li, H.Q., Wang, R.S., Paulussen, J., He, Y., Wang, M., Wang, B.H., Wang, Z., (2006). Monitoring and predicting land use change in Beijing using remote sensing and GIS. Landscape Urban Plann $78,322-333$. 